\title{
The short-term debt choice under asymmetric information
}

\author{
David Abad $^{1}$ - Juan Pedro Sánchez-Ballesta ${ }^{2}$. \\ José Yagüe $^{3}$ (iD
}

Received: 26 October 2016 / Accepted: 7 August 2017 / Published online: 1 September 2017 (C) The Author(s) 2017. This article is an open access publication

\begin{abstract}
This paper investigates whether the market level of information asymmetry affects firms' debt financing decisions. Using a sample of non-financial listed firms and a composite index based on microstructure measures of information asymmetry, we find that firms with more information asymmetry use shorter debt maturities. In addition, we find that these firms face more difficulties to access public debt and bank debt (particularly, short-term bank debt), and they have to rely on trade credit as an alternative source of short-term financing. Analyzing the associations in two subsamples based on firm size, we find that our results essentially driven by smaller companies, which are those affected by higher information asymmetries. Our findings support the information asymmetry theories of trade credit: as information asymmetry increases and, consequently, listed firms face more constraints in the credit markets, they increase the use of financing provided by their suppliers.
\end{abstract}

Keywords Information asymmetry $\cdot$ Market microstructure $\cdot$ Short-term debt $\cdot$ Bank debt $\cdot$ Accounts payable $\cdot$ Trade credit

\osé Yagüe

ppyague@um.es

David Abad

goliat@ua.es

Juan Pedro Sánchez-Ballesta

juanpsb@um.es

1 Department of Financial Economics and Accounting, Faculty of Economics and Business

Sciences, University of Alicante, San Vicente de Raspeig, 03690 Alicante, Spain

2 Department of Accounting, Faculty of Economy and Business, University of Murcia, Campus de Espinardo, 30100 Murcia, Spain

3 Department of Management and Finance, Faculty of Economy and Business,

University of Murcia, Campus de Espinardo, 30100 Murcia, Spain 
JEL Classification G14 · G32

\section{Introduction}

The information environment of a firm, in general, and the level of information asymmetry between better-informed insiders and less-informed investors, in particular, plays a fundamental role in the financing decisions of firms. From the seminal work of Myers and Majluf (1984), there is an extensive theoretical and empirical literature showing that information asymmetry has important implications in firms' financial decisions, such as financing choices between debt and equity (Myers and Majluf 1984), public and private debt (e.g. Leland and Pyle 1977; Diamond 1984; Fama 1985), debt maturity choice (e.g. Flannery 1986; Barclay and Smith 1995; Berger et al. 2005), and the choice between bank and non-bank debt (e.g. Johnson 1997; Anderson and Makhija 1999).

Most papers on corporate finance that examine financing decisions focus on the agency conflict between insiders and creditors, and they commonly use information asymmetry proxies based on financial and accounting characteristics of the firm such as size, growth options, or earnings opacity. More recently, some researchers have been addressing financing questions by looking at information asymmetry proxies from the trading process in the stock market (Bharath et al. 2009; Gao and Zhu 2015; Shen 2014; Petacchi 2015). Market microstructure is the branch of literature providing these measures which proxy the market perception of the information advantage held by insiders and the adverse selection risk faced by outsiders (Bharath et al. 2009).

In this paper, we follow the market microstructure approximation to examine an empirical question that, to the best of our knowledge, has not been previously addressed: whether the information asymmetry concerning firms' market valuation affects their short-term financing structure. To do so, we focus on the Spanish case, a market with high levels of short-term debt combined with a bank-oriented financial system. We analyze whether the degree of information asymmetry associated with a firm affects the choice between the different alternative sources of short-term private debt financing, i.e., bank debt and trade credit. In addition, since the choice of shortterm financing may be determined by restrictions in the public debt market and/or in the long-term private debt market, we also analyze the influence of information asymmetries on debt maturity, public debt and long-term bank debt.

Previous financial research shows the significance of adverse selection costs in debt maturity choices by firms. A great number of studies find that firms with higher information asymmetries show shorter debt maturities (Barclay and Smith 1995; Stohs and Mauer 1996; Scherr and Hulburt 2001; Berger et al. 2005). These findings validate the empirical predictions of Flannery's (1986) and Diamond's (1991) theoretical models: (1) firms with larger levels of information asymmetries and favorable private information are more likely to issue short-term debt because they can obtain this debt at a low interest rate and roll it over (Berger et al. 2005). (2) Under asymmetric information, short-term debt facilitates monitoring, because lenders can refuse or modify the terms of the loans, which is particularly important in financing supplied by banks (Diamond 1991; Magri 2010). 
Focusing on the different types of short-term financing, extensive examples in the literature show that one of its main determinants is the adverse selection and moral hazard problems due to the information asymmetry faced by lenders. DemirgüçKunt and Maksimovic (2002) and De Andrés Alonso et al. (2005) hypothesize that companies' access to bank financing differs in market-based and bank-based financial systems. In market-based financial systems, firms with higher information asymmetry use more bank debt than public debt (e.g. Johnson 1997; Anderson and Makhija 1999; Denis and Mihov 2003). Due to their closer relationship with the firms, banks and other private lenders are more effective at monitoring borrowers, and consequently have an informational advantage over lenders in the public debt market (Leland and Pyle 1977; Diamond 1984; Fama 1985). Hence, firms with a higher degree of information asymmetry will borrow privately, while firms with lower information asymmetry will prefer public debt (Denis and Mihov 2003).

On the contrary, in a bank-based financial system, most firms deal almost exclusively with financial intermediaries and the possibility of substituting market debt for bank debt is limited to a very few large firms. In this context, an increase in the information asymmetry can impair the access to bank debt (De Andrés Alonso et al. 2005; García-Teruel et al. 2014b) and create bank credit rationing (Stiglitz and Weiss 1981). Consequently, there is an incentive for constrained firms to use more trade credit as a short-term financing alternative, since suppliers might be better skilled at overcoming informational asymmetries and enforcement problems than financial institutions (Love 2011).

Several theoretical papers support the relationship between bank credit rationing and trade credit driven by information asymmetries (e.g. Smith 1987; Biais and Gollier 1997; Jain 2001; Burkart and Ellingsen 2004). According to the implications of these papers, suppliers can provide trade credit to firms when institutional credit is not available since suppliers present advantages over banks and other lenders: (1) suppliers can obtain better information on the borrower's creditworthiness than banks, (2) they face lower monitoring costs, (3) they can control the debtor better through the delivery of goods supplied, and (4) they can liquidate assets more efficiently (Petersen and Rajan 1997). Consistently, the majority of the empirical evidence finds that firms increase their demand for trade credit to overcome financial constraints and that suppliers may act as liquidity providers in situations of credit rationing (e.g. Petersen and Rajan 1997; Nilsen 2002; Danielson and Scott 2004; Cuñat 2007; Garcia-Appendini and Montoriol-Garriga 2013). Accordingly, we hypothesize that information asymmetry among investors is positively (negatively) related to the level of trade credit (short-term bank debt).

In corporate finance, information asymmetry refers to the notion that insiders, typically the managers, know more about the quality and value of their firm's assets than outsiders do. This asymmetry creates the possibility that the market will not price the firm's claims correctly (Klein et al. 2002) and the insiders take advantage of the firm's misvaluation. Since measuring information asymmetry is a difficult task, studies on financial decisions have used different proxies such as the amount of growth options in a firm's investment opportunity set (Barclay and Smith 1995), firm size (Stohs and Mauer 1996; Scherr and Hulburt 2001), risk ratings (Berger et al. 2005), and accounting quality (Bharath et al. 2008; García-Teruel et al. 2014a, b). However, 
stock markets play an important role in the transmission of useful information to creditors (Demirgüç-Kunt and Maksimovic 1999) since stock prices partially reveal information that is in the possession of informed traders.

In the market microstructure literature it is well recognized that, when people trade, there are some participants with better information (informed traders) than others (uninformed traders) about the fundamental value of the asset. In fact, firm managers and insiders are typically considered as informed agents. Market microstructure literature has proposed different measures to capture the adverse selection faced by an uninformed investor when trading a stock, and thus proxy for the information asymmetry level of the firm. As Bharath et al. (2009) point out, market microstructure measures of information asymmetry are proxies for the financial markets' perception of the information advantage held by firm insiders and the adverse selection risk borne by outsiders. ${ }^{1}$ On this basis, recent empirical research has used market microstructure proxies for adverse selection to analyze whether the capital structure of firms is driven by asymmetric information (i.e., Agarwal and O'Hara 2007; Bharath et al. 2009; Shen 2014; Gao and Zhu 2015). Thus, Bharath et al. (2009) document a positive relationship between information asymmetry and leverage, and Shen (2014) finds that firms have more difficulties to access public debt as the level of information asymmetry increases. However, whereas these papers have focused mainly on capital structure to test the pecking order theory, in this paper we use this approximation to deal with a fundamental question in bank-based financial countries and which has scarcely been examined by the prior literature on listed companies: the effect of information asymmetries on debt structure, and particularly, on the short-term financing decision.

In order to capture the extent of information asymmetry, we use a composite index based on market microstructure measures estimated from high frequency data: the bid-ask spread, the illiquidity measure developed in Amihud (2002), the price impact introduced by Huang and Stoll (1996), the Probability of Informed Trading (PIN) of Easley et al. (1996), and the new Volume-Synchronized Probability of Informed Trading (VPIN) of Easley et al. (2012). With the index of information asymmetry, we extract the common variation in these information asymmetry proxies, so minimizing the possibility that these measures are driven by factors other than adverse selection (such as inventory costs, transactions costs, monopoly rents, etc.).

To test our hypothesis, we use a panel of non-financial firms listed in the Spanish Stock Exchange (SIBE) for the period 2001-2008. ${ }^{2}$ Spain is classified as a code law country characterized by weak investor protection, a high concentration of ownership and a less developed capital market than Anglo-Saxon countries (La Porta et al. 1998; Faccio and Lang 2002). Moreover, Spain is a clear example of a country with a

\footnotetext{
${ }^{1}$ Bharath et al. (2009) affirm that the market microstructure measures of information asymmetry are more desirable than those provided by corporate finance literature. On one hand, the literature documents that market microstructure measures are sensitive to a wide array of potentially informative corporate events (earnings, dividends, takeovers, etc.) and firm characteristics (credit rating, ownership structure, etc.). On the other hand, corporate finance proxies (firm size, analyst's coverage, etc.) are often inconsistent, as well as inherently static and persistent, having multiple and often ad hoc interpretations.

2 In terms of market capitalization and trading volume, the Spanish Stock Exchange was one of the largest stock markets in 2005, midpoint of our sample period (see the 2006 World Federation of Exchanges annual report: http://www.world-exchanges.org/insight/reports/2006-wfe-annual-report).
} 
banking-oriented financial system in which few firms issue public debt (basically listed companies) and where banks and suppliers are the main sources for firm financing (Schmidt and Tyrell 1997; Demirgüç-Kunt and Maksimovic 2002). In contrast to US firms, Spanish companies present a very different debt maturity structure showing higher levels of short-term debt. According to the data from Central de Balances del Banco de España (CBBE), the mean value of short-term debt over total debt was $57.6 \%$ in 2008 for Spanish firms, much higher than the $21 \%$ presented by US companies (Datta et al. 2005). ${ }^{3}$ Moreover, short-term debt financing and trade credit have significant relevance in the Spanish financial system. In particular, trade credit in Spanish firms is one of the highest in Europe (Marotta 2005) representing 23.7\% of total debt and $41.2 \%$ of total short-term debt in 2008 (according to the data provided by CBBE).

Our findings show that market microstructure measures of information asymmetry explain debt structure and, in particular, short-term debt financing decisions of listed firms. Our results reveal that information asymmetry in the stock market reduces firms' debt maturity, i.e., firms face more restrictions to obtain long term debt. In addition, firms with higher informational asymmetries face more difficulties in accessing public debt and bank debt, in particular short-term bank debt. Thus, in their choice between short-term financing sources, they have to rely on account payables as an alternative source of financing to overcome the financial constraints induced by information asymmetry problems.

Since firm size is a commonly considered proxy for the quantity and quality of information available about a firm (e.g., Barry and Brown 1984; Atiase 1985; Bhushan 1989; Bhattacharya et al. 2013), we further investigate the effects of information asymmetry on short-term financing by splitting our sample into small and large firms. We find that information asymmetry is a significant determinant both of the level of short-term debt and the types of financing sources for small firms (characterized by a poorer information environment). Hence, for smaller listed firms, we find a negative association between information asymmetry and financial funds obtained in the credit markets (public and bank debt), and that the relevance of trade credit enhances as information asymmetries increases. For larger listed firms, we also find a positive relationship between information asymmetry and the weight of trade credit within the short-term debt. However, our findings suggest that financing decisions are less sensitive to information asymmetry in larger listed firms, probably because the information asymmetry problem is not as severe as in smaller firms.

Our paper contributes to the literature by examining the implications for corporate decisions of information asymmetry in the equity market. Specifically, our paper extends the strand of empirical papers that use measures from market microstructure literature to explain firm's capital structure decisions (Agarwal and O'Hara 2007; Bharath et al. 2009; Shen 2014; Gao and Zhu 2015). Unlike these studies, we do not examine the firm's decision to issue debt or equity when raising capital, but we focus on the debt structure, and particularly on the short-term financing decision. Thus, we

\footnotetext{
3 Central de Balances del Banco de España (Central Balance Sheet Data Office of Bank of Spain) is a division of the Statistics Department of the Spanish central bank, which publishes the annual series of financial information (balance sheets, income statements, ratios, etc.) of Spanish non-financial corporations.
} 
analyze how information asymmetry affects debt maturity, the choice between public and private debt, and the firm's short term debt financing decision between bank debt and trade credit. As a consequence, from an informational perspective, our paper contributes to the financial literature concerning the firm's choice of short-term financial sources. Our findings suggest a substitutive relationship between trade credit and bank credit, which is consistent with the information asymmetry theories of trade credit.

The rest of the paper proceeds as follows. Section 2 describes the measure of information asymmetry, model specifications, and the sample. Section 3 reports the empirical results and the final section concludes the paper.

\section{Research design}

\subsection{Measuring information asymmetry}

In contrast to the corporate finance measures based on firm characteristics, market microstructure literature has proposed measures of information asymmetry that capture financial market perception about adverse selection risk, which arises from the presence of informed traders. Since information asymmetry is not directly observable, all measures proposed could be considered as imperfect or incomplete proxies of the adverse selection between informed and uninformed traders. To obtain a more complete information asymmetry measure, prior studies apply principal component analysis to individual proxies to enhance the final measurement (e.g. Bharath et al. 2009). We follow this approach and create an adverse selection index (ASY, hereafter) from five individual measures developed by market microstructure literature: the relative bid-ask spread, the illiquidity measure developed in Amihud (2002), the price impact introduced by Huang and Stoll (1996), the PIN, and the VPIN. Next, we describe the calculation of the five components of the index.

Bid-ask spread is a measure of trading costs (liquidity), which is commonly used to proxy for information asymmetry as it compensates liquidity providers for transacting with better-informed traders (Glosten and Milgrom 1985). We calculate the relative quoted spread, $R Q S$, which is the difference between the bid and ask quotes in time $t$ scaled by the quote mid-point. First, we computed $R Q S$ on a daily basis by averaging (time-weighted) all the observations within the day. Following that, we obtain an annual $R Q S$ by averaging (equally-weighted) daily values.

Since adverse selection is an important determinant of stock liquidity, we estimate the index of illiquidity introduced by Amihud (2002), which is a volume-based liquidity indicator $(A M H$, hereafter). This measure reflects the average of the daily price impact of the order flow. When a stock is liquid, large trading volumes provoke small price changes. Therefore, higher values of $A M H$ indicate higher price movements in response to trading volume and thus, higher stock illiquidity. It is expected that the greater the information asymmetry, the worse the stock liquidity, and the higher the $A M H$ and $R Q S$ values.

We also include the measure of price impact $(P I)$ developed by Huang and Stoll (1996), $P I$ is the permanent price change or information content of a trade, which is estimated based on the differences in the true economic value of the security (proxied 
by the quote mid-point) before and after the transaction. As Huang and Stoll (1996), we calculate the price impact over a 30-min interval. A daily PI is computed in tradetime by averaging (volume-weighted) all the trades within the day. Then, we obtain an annual value by averaging (equally weighted) all the trading days within the year. A large and positive PI indicates a high frequency of information-based trades.

The fourth and fifth constituents of our index, the well-known PIN and the novel VPIN, directly infer the information content of the trading process from the computation of order imbalances between buys and sells. The PIN is the unconditional probability that a randomly selected trade originates from an informed trader. Consequently, the higher PIN value, the greater is a firm's extent of information asymmetry. The original PIN model was introduced by Easley et al. (1996). We estimate first the PIN model via maximum likelihood per stock and month. The use of 1-month transaction data should be wide enough to produce reliable estimates and allows us to maximize the number of estimations. ${ }^{4}$ Finally, we calculate an annual PIN by averaging monthly values.

As an update of the PIN model, Easley et al. (2012) have developed a new measure for adverse selection risk called VPIN. In particular, VPIN measures order flow toxicity, which can be considered as a broader concept for adverse selection applied to the particular world of liquidity providers in a high frequency trading (HFT) environment. However, VPIN can be considered as a more flexible measure of asymmetric information that can be applied in a wide range of frameworks by choosing the appropriate values of the variables involved in its computation (Abad and Yagüe 2012). There are three relevant variables in the VPIN approach: time bar, volume bucket and sample length. ${ }^{5}$ At bar level, trade flow is split between buys and sells. At bucket level, order imbalances are computed. Finally, order imbalances are smoothed in the sample length by computing a moving average and the VPIN series is obtained. An annual VPIN is computed by averaging all the values of the result VPIN series into the year.

\subsection{Model specification}

To study the influence of the level of information asymmetry in the market on the debt financing decisions of the firm, we run several regressions modeling each of the proxies for the debt financing choices as a function of the level of information asymmetry:

$$
\text { Debt Type }=\beta_{0}+\beta_{1} A S Y+\sum_{j} \beta_{j} \text { Controls }+\varepsilon
$$

where the dependent variable DebtType represents different debt ratios that capture the external financing choice of firms, and which are described below; $A S Y$ is the index of information asymmetry, and Controls represents the control variables included in the models.

\footnotetext{
${ }^{4}$ Easley et al. (1997) indicate that a 30 trading-day window ensures sufficient trade observations for the PIN estimation procedure. Akay et al. (2012) use 20 trading days to estimate PIN finding numerical solutions for all their estimations.

${ }^{5}$ For an accurate description of the procedure, see the original paper of Easley et al. (2012). For a numeric example of this procedure, see Abad and Yagüe (2012).
} 
Firstly, we consider the effect of information asymmetry on the term of the debt, so we define as dependent variable the ratio of short-term debt to total debt, SHTDBT. We consider as short-term that debt, regardless of its type, which has a maturity of up to 1 year. According to the literature on debt maturity structure, we expect a positive association between $A S Y$ and $S H T D B T$, since, from a borrower perspective, firms facing high information asymmetries and with good private credit quality, can obtain better conditions when renewing their short-term debt, and, from a lender perspective, short-term debt facilitates the monitoring of firms with high information asymmetry.

As a second analysis, and although not many firms, mainly the larger ones, issue public debt in Spain, we are interested in the choice between public and private debt. Thus, we define our second dependent variable $P B L D B T$ as the ratio of public debt to total debt, and we expect a negative coefficient on $A S Y$ in the model of PBLDBT. Since private lenders have more access to private information, superior ability to monitoring firms, and more flexibility in designing contracts than public lenders (Leland and Pyle 1977; Diamond 1984; Fama 1985; Bharath et al. 2008), we expect that firms with higher information asymmetries in the capital market will have more difficulties in obtaining public debt and thus will have to rely on private debt (Denis and Mihov 2003; De Andrés Alonso et al. 2005).

Once analyzed the influence of $A S Y$ on the term of the debt (short/long) and the type of market debt, public and private, we are interested in examining how information asymmetry influences the access to debt in the private debt market. In the subsequent analyses we study the association between $A S Y$ and bank debt, on one hand, and trade credit, on the other. We define our third dependent variable $B N K D B T$ as the ratio of bank debt over total debt, and then we decompose $B N K D B T$ into long-term and short-term bank debt. $L N G B N K$, our fourth dependent variable, is the ratio of longterm bank debt over total debt; $S H T B N K$, our fifth dependent variable, is the ratio of short-term bank debt to total debt; and $A C C P A Y$, our sixth dependent variable, is the ratio of accounts payable to total debt. As a final analysis to examine in depth the firm's choice of short-term financial sources under asymmetric information, we define our seventh dependent variable, TRDCRD, as the ratio of accounts payable to the sum of short-term bank debt plus accounts payable. Based on information asymmetry theories of trade credit, if firms with higher information asymmetries face bank credit rationing they will use more trade credit instead (Smith 1987; Biais and Gollier 1997). Thus, we expect negative coefficients on $A S Y$ in the BNKDBT, LNGBNK, and $S H T B N K$ regressions, ${ }^{6}$ as well as positive coefficients on $A S Y$ in the ACCPAY and TRDCRD regressions.

Following previous studies, we include several controls in our models in order to take into account the influence of size, leverage, internal funds, asset maturity, growth options, collateral, solvency, and income volatility (Petersen and Rajan 1997; Danielson and Scott 2004; Bharath et al. 2009; Magri 2010): SIZE is the logarithm of sales; $L E V$ is the leverage ratio calculated as total debt over total assets; CFOTA is the ratio of cash flow (net income plus depreciation) over total assets. $L A M$ is the

\footnotetext{
6 There is also the possibility that higher information asymmetry leads to a reduction in the term of bank debt, with an increase in short-term bank debt and a reduction in long-term bank debt but without bank credit rationing. In this case, the coefficient on $B N K D B T$ would be non-significant.
} 
logarithm of asset maturity; BTM is the book-to-market ratio; TANG is the ratio of tangible fixed assets over assets. $Z$ is the re-estimated Altman Z-score by Begley et al. (1996). $\sigma(R O A)$ is the standard deviation of return on assets from $t-2$ to $t$. Finally, we include dummy variables to control for industry and year effects.

\subsection{Sample and data}

Our sample is made up of stocks traded on the electronic trading platform of the Spanish Stock Exchange, known as the SIBE (Sistema de Interconexión Bursátil Español). The SIBE is an order-driven market where liquidity is provided by an open limit order book. Trading is continuous from 9:00 a.m. to 5:30 p.m. There are two regular call auctions each day: the first one determines the opening price (8:30-9:00 a.m.), and the second sets the official closing price (5:30-5:35 p.m.). Three basic types of orders are allowed: limit, market, and market-to-limit orders. In the continuous session, a trade occurs whenever an incoming order matches one or more orders on the opposite side of the limit order book. Orders submitted that are not instantaneously executed are stored in the book according to a strict price-time priority rule. Unexecuted orders can always be cancelled and modified. Continuous trading may be temporally interrupted since a system of stock-specific intraday price limits and short-lived call auctions is implemented to handle unusual volatility levels. In all auctions (open, close and volatility) orders can be submitted, modified or cancelled, but no trades occur.

Trade and quote data for this study come from SM data files provided by Sociedad de Bolsas, S.A. SM files comprise detailed time-stamped information about the first level of the limit order book for each stock listed on the SIBE. Any trade, order submission or cancellation affecting best prices in the book generate a new record. The distinction between buyer-initiated and seller-initiated trades is straightforward, without the need to use a classification algorithm. Firms' financial statement data are obtained from the SABI database, made by Bureau Van Dijk, and the annual accounts stored at the registration files of Spanish Securities Market Commission (Comisión Nacional del Mercado de Valores, CNMV). Institutional ownership and analysts' data come from Thomson Reuters Eikon Datastream.

The initial sample consists of all non-financial firms listed on the main segment of the SIBE in the period 2001-2008. After applying the usual filters to detect and eliminate errors in the preparation of the intraday trading data and the financial data, we consider those firm-year observations for which we have been able to collect debt figures, the information asymmetry measures and the control variables. The final sample consists of 100 firms and 543 firm-year observations.

\section{Empirical results}

\subsection{Information asymmetry index properties}

Table 1 presents a summary of $A S Y$, our proxy for the risk of adverse selection among investors. Panel A reports mean value, standard deviation and percentiles 10, 50 and $90 \%$ for the five constituents and the index. The mean (median) of relative bid-ask 
Table 1 Information asymmetry index

\begin{tabular}{|c|c|c|c|c|c|c|}
\hline & $\mathrm{N}$ & Mean & $\mathrm{SD}$ & 10th perc. & Median & 90th perc. \\
\hline \multicolumn{7}{|c|}{ Panel A: Descriptive statistics } \\
\hline$R Q S$ & 543 & 0.0064 & 0.0062 & 0.0013 & 0.0042 & 0.0143 \\
\hline$A M H$ & 543 & 0.2802 & 1.9275 & 0.0005 & 0.0084 & 0.3382 \\
\hline$P I$ & 543 & 0.0038 & 0.0028 & 0.0011 & 0.0030 & 0.0076 \\
\hline$P I N$ & 542 & 0.1885 & 0.0608 & 0.1218 & 0.1787 & 0.2645 \\
\hline$V P I N$ & 543 & 0.2017 & 0.1230 & 0.0731 & 0.1719 & 0.3595 \\
\hline$A S Y$ & 542 & 0.0000 & 1.7868 & -1.8772 & -0.4015 & 2.4043 \\
\hline ASY between & 100 & & 1.6980 & & & \\
\hline ASY within & 5.42 & & 0.7552 & & & \\
\hline & $A S Y$ & $R Q S$ & $A M H$ & $P I$ & PIN & VPIN \\
\hline \multicolumn{7}{|c|}{ Panel B: Correlation matrix } \\
\hline$A S Y$ & 1 & & & & & \\
\hline$R Q S$ & $0.9150 * * *$ & 1 & & & & \\
\hline$A M H$ & $0.4579 * * *$ & $0.3031 * * *$ & 1 & & & \\
\hline$P I$ & $0.8445^{* * *}$ & $0.9171 * * *$ & $0.2066^{* * *}$ & 1 & & \\
\hline PIN & $0.8305^{* * *}$ & $0.6087 * * *$ & $0.3456^{* * *}$ & $0.5107 * * *$ & & \\
\hline$V P I N$ & $0.8618^{* * *}$ & $0.6875 * * *$ & $0.3141 * * *$ & $0.5579 * * *$ & $0.7796 * * *$ & 1 \\
\hline
\end{tabular}

Panel A reports descriptive statistics of market microstructure measures of information asymmetry used in this study. $R Q S$ is the relative quote bid-ask spread. $A M H$ is the illiquidity measure of Amihud (2002). PI is the price impact measure proposed by Huang and Stoll (1996). PIN is Probability of Informed Trading based on the Easley et al. (1996) model. VPIN is Volume-Synchronized Probability of Informed Trading developed in Easley et al. (2012). ASY is the composite index of information asymmetry based on the former measures of information asymmetry (RQS, AMH, PI, PIN, and VPIN). ASY between and ASY within show the between firm and within firm standard deviations of $A S Y$, respectively. Panel B reports correlation coefficients between the composite index of information asymmetry and the constituents of the index used in this study. $* * *$ Denotes significance levels at two-tail tests of $1 \%$

spread $(R Q S)$ is $0.64 \%(0.42 \%)$. The mean value of $A M H$ in our sample $(0.28)$ is similar to that reported by Amihud (2002). The average (median) of price impact measure $(P I)$ is $0.38 \%(0.30 \%)$. The probability of informed trading $(P I N)$ shows a mean (median) value of around $19 \%(18 \%)$. These PIN values are consistent with those reported in prior studies (e.g. Brown and Hillegeist 2007). The VPIN shows a similar mean value to the PIN.

In order to isolate the common adverse selection component underlying the five proxies we construct an index of information asymmetry $(A S Y)$ using principal component analysis across firm-years for the whole sample. The mean of $A S Y$ is zero (by construction) and its median is -0.40 . The statistical distributions of the above measures show that there are clear differences in the degree of asymmetric information between the firms included in our sample. Moreover, in ASY between and ASY within rows we report the between firm (1.70) and within firm (0.76) standard deviations of 
ASY, respectively. ${ }^{7}$ These values show that the main source of variation in our sample is between firms, so in the following analyses we are interested in examining how debt financing is affected by cross-sectional differences in information asymmetry, proxied by $A S Y$. The first (and only) factor with an eigenvalue greater than one explains $64.3 \%$ of the variance and each component of $A S Y$ enters with positive sign and weights as follows:

$$
A S Y=0.513 R Q S+0.258 A M H+0.470 P I+0.465 P I N+0.483 V P I N
$$

Therefore, each proxy for information asymmetry plays its role in the index. A higher value of the index means a higher level of information asymmetry. Panel B of Table 1 provides the Pearson correlation matrix between the constituents of the index and the index itself. All the information asymmetry proxies are positively correlated with each other indicating that these measures are likely to be driven by adverse selection, although each contains unique information. Moreover, the index is positively and significantly correlated with each information asymmetry variable, varying from a correlation of $92 \%$ between $A S Y$ and $R Q S$ to a correlation of $46 \%$ between $A S Y$ and $A M H$. Moreover, correlations between each of the five proxies for information asymmetry and the index are generally higher than the correlations between each other, suggesting that the index is a parsimonious measure of information asymmetry.

We also analyse whether our index is consistent with several firm characteristics commonly used to measure the degree of firms' information asymmetry by the corporate finance literature. In particular, as seen in Table 2, we sort firms by ASY in quintiles (in levels and annual variations) and report the average values of five firm characteristics (assets, sales, age, analysts' coverage and institutional ownership) in each quintile of $A S Y$. In addition, we obtain Spearman rank correlations and the linear regression slope coefficients relating $A S Y$ with the corporate finance proxies. Prior literature has provided extensive evidence showing that larger and older firms, as well as firms more followed by analysts and with higher levels of institutional ownership, suffer lower information asymmetry problems. As seen in Panel A, the average values of these firm characteristics decrease as we move to higher adverse selection quintiles. The negative and significant values of correlations and slope coefficients corroborate the expected inverse relationship between the composite index and firm characteristics considered as typical proxies for information asymmetries. When we look at the results in terms of year-on-year fluctuations (Panel B), we observe that the relationship does not follow any systematic behaviour and that the correlation and slope coefficients become insignificant.

In short, Table 2 suggests that (1) the composite index is valid to test whether the information asymmetry problems affect capital structure decisions, and (2) the variability of corporate finance measures affecting information asymmetry comes from

\footnotetext{
${ }^{7}$ In our analyses we use annual values of our proxies for information asymmetry. We have also calculated monthly values of them. The variation of these measures within firms and between firms at the monthly basis is similar to that observed at the annual basis. For instance, the standard deviation of ASY between firms is 1.43 and within firms is 0.88 by using monthly data.
} 
Table 2 Accounting and firm environment variables across adverse selection quintiles

\begin{tabular}{|c|c|c|c|c|c|}
\hline Quintile & Assets & Sales & Age & Analysts & Inst_own \\
\hline \multicolumn{6}{|c|}{ Panel A: $A S Y$ based quintiles } \\
\hline 1 & 16.15 & 15.49 & 3.76 & 19.5 & 0.17 \\
\hline 2 & 14.68 & 13.96 & 3.62 & 11.84 & 0.12 \\
\hline 3 & 14.09 & 13.75 & 3.70 & 8.79 & 0.14 \\
\hline 4 & 13.21 & 12.79 & 3.58 & 6.69 & 0.13 \\
\hline 5 & 12.60 & 12.18 & 3.40 & 4.14 & 0.11 \\
\hline$r$ & $-0.71 * * *$ & $-0.68 * * *$ & $-0.13 * * *$ & $-0.73 * * *$ & $-0.26 * * *$ \\
\hline$b^{O L S}$ & $-0.58 * * *$ & $-0.54 * * *$ & $-0.44 * * *$ & $-0.15^{* * *}$ & $-3.08 * * *$ \\
\hline \multicolumn{6}{|c|}{ Panel B: $\triangle A S Y$ based quintiles } \\
\hline 1 & 13.57 & 13.14 & 3.54 & 6.87 & 0.13 \\
\hline 2 & 14.59 & 14.10 & 3.83 & 11.66 & 0.15 \\
\hline 3 & 14.81 & 14.23 & 3.66 & 13.47 & 0.16 \\
\hline 4 & 14.75 & 14.31 & 3.75 & 13.58 & 0.15 \\
\hline 5 & 13.42 & 12.97 & 3.52 & 7.54 & 0.12 \\
\hline$r$ & 0.004 & 0.008 & -0.011 & 0.042 & -0.062 \\
\hline$b^{O L S}$ & -0.006 & -0.002 & 0.002 & $-0.2 \mathrm{e}-3$ & -0.34 \\
\hline
\end{tabular}

This table reports means of various firm characteristics for each adverse selection quintile. Assets is the logarithm of total assets. Sales is the logarithm of sales. Age is the logarithm of the numbers of years since the inception. Analysts is the number of analysts following a firm. Inst_own is the percentage of shares owned by institutional shareholders. $r$ and $b^{O L S}$ are the Spearman rank correlation and linear regression coefficient, respectively, between the corresponding variable and either $A S Y$ or $\triangle A S Y$ based rankings. *** Denotes significance levels at two-tail tests of $1 \%$

the cross-section (among firms) rather than from the relative change in each company (within firms). These findings are consistent with those in Bharath et al. (2009).

\subsection{Descriptive statistics and preliminary analyses}

Table 3 reports summary statistics for the dependent (Panel A) and control variables (Panel B), showing their mean values, standard deviations and percentiles 10, 50 and $90 \%$. The mean (median) of SHTDBT is $59.41 \%$ (57.68\%), which shows the relevance of short-term debt in Spanish listed firms. PBLDBT has a mean and a median of 6.15 and $0 \%$, respectively. The median value is zero because only 184 firm-year observations ( $33 \%$ of our sample) issue public debt. This is consistent with the notion that the Spanish capital market is dominated by private (bank and non-bank) debt providers (Ojah and Manrique, 2005:455), and that few firms resort to public debt issuances in order to obtain external financing. Within the private debt, the mean (median) of $B N K D B T$ is $38.16 \%$ (37.84\%), with the weight of long-term bank debt over total debt being higher than that of short-term bank debt. Thus, LNGBNK shows a mean (median) value of $21.30 \%(19.09 \%)$, whereas the mean (median) of SHTBNK is $16.87 \%(11.73 \%)$. 
Table 3 Descriptive statistics of dependent and control variables

\begin{tabular}{|c|c|c|c|c|c|c|}
\hline & $\mathrm{N}$ & Mean & $\mathrm{SD}$ & 10th perc. & Median & 90th perc. \\
\hline \multicolumn{7}{|c|}{ Panel A: Financing measures } \\
\hline SHTDBT & 543 & 0.5941 & 0.2129 & 0.3100 & 0.5768 & 0.8964 \\
\hline$P B L D B T$ & 543 & 0.0615 & 0.1213 & 0.0000 & 0.0000 & 0.2774 \\
\hline$B N K D B T$ & 543 & 0.3816 & 0.2122 & 0.0753 & 0.3784 & 0.6462 \\
\hline$L N G B N K$ & 543 & 0.2130 & 0.1645 & 0.0080 & 0.1909 & 0.4468 \\
\hline$S H T B N K$ & 543 & 0.1687 & 0.1571 & 0.0238 & 0.1173 & 0.3721 \\
\hline АCCPAY & 543 & 0.2733 & 0.1736 & 0.0836 & 0.2379 & 0.5102 \\
\hline$T R D C R D$ & 543 & 0.6202 & 0.2431 & 0.3007 & 0.6208 & 0.9353 \\
\hline \multicolumn{7}{|c|}{ Panel B: Control variables } \\
\hline$L E V$ & 543 & 0.6179 & 0.1859 & 0.3398 & 0.6431 & 0.8374 \\
\hline SIZE & 543 & 13.6285 & 1.8589 & 11.5475 & 13.6947 & 16.0709 \\
\hline CFOTA & 543 & 0.0772 & 0.0825 & 0.0312 & 0.0764 & 0.1527 \\
\hline$L A M$ & 543 & 1.8195 & 0.9112 & 0.7979 & 1.7848 & 2.8430 \\
\hline$B T M$ & 543 & 0.6278 & 0.4868 & 0.1795 & 0.5551 & 1.2171 \\
\hline$T A N G$ & 543 & 0.3461 & 0.2157 & 0.0696 & 0.3204 & 0.6339 \\
\hline$Z$ & 543 & 0.4997 & 0.5479 & 0.2152 & 0.4254 & 0.8031 \\
\hline$\sigma(R O A)$ & 543 & 0.0265 & 0.0304 & 0.0046 & 0.0159 & 0.0611 \\
\hline
\end{tabular}

This table reports descriptive statistics of the variables employed in the present study. SHTDBT is the ratio of short-term debt to total debt. $P B L D B T$ is the ratio of public debt to total debt. BNKDEBT is the ratio of bank debt to total debt. $L N G B N K$ is the ratio of long-term bank debt to total debt. SHTBNK is the ratio of short-term bank debt to total debt. ACCPAY is the ratio of accounts payable to total debt. TRDCRD is the ratio of accounts payable to the sum of short-term bank debt plus accounts payable. $L E V$ is the total debt over total assets. SIZE is the logarithm of sales. CFOTA is the ratio of operating cash flow to total assets. $L A M$ is the logarithm of asset maturity. BTM is the logarithm of the book-to-market value of equity ratio. $T A N G$ is the ratio of net equipment and gross plants to total assets. $Z$ is the re-estimated Altman Z-score by Begley et al. (1996). $\sigma(R O A)$ is the standard deviation of return on assets from $t-2$ to $t$

Regarding the other component of private debt, ACCPAY represents, on average (median), $27.33 \%$ (23.79\%) of total debt. Therefore, the financing provided by suppliers is the main source of the short-term financing of our sample's firms. This result is in line with the evidence reported in the majority of developed and industrialized countries, where the volume of trade credit exceeds the volume of short-term bank debt (e.g. Rajan and Zingales 1995). TRDCRD mean value of $62.02 \%$ confirms the importance of trade credit in the short-term financing of our sample. These values are consistent with those reported in prior studies (e.g., García-Teruel et al. 2014a). With regard to control variables, the significant level of dispersion in the values of these variables reflects the heterogeneity of our firm-year sample.

Table 4 presents the Pearson correlation matrix between the variables used in the analyses. As seen, SHTDBT is negatively correlated with PBLDBT and BNKDBT (at the $1 \%$ level), which is consistent with the fact that public debt and bank debt of Spanish non-financial listed firms are mainly long-term financing. SHTDBT is also positively correlated with $S H T B N K$ and ACCPAY (at the 1\% level), respectively. These two 


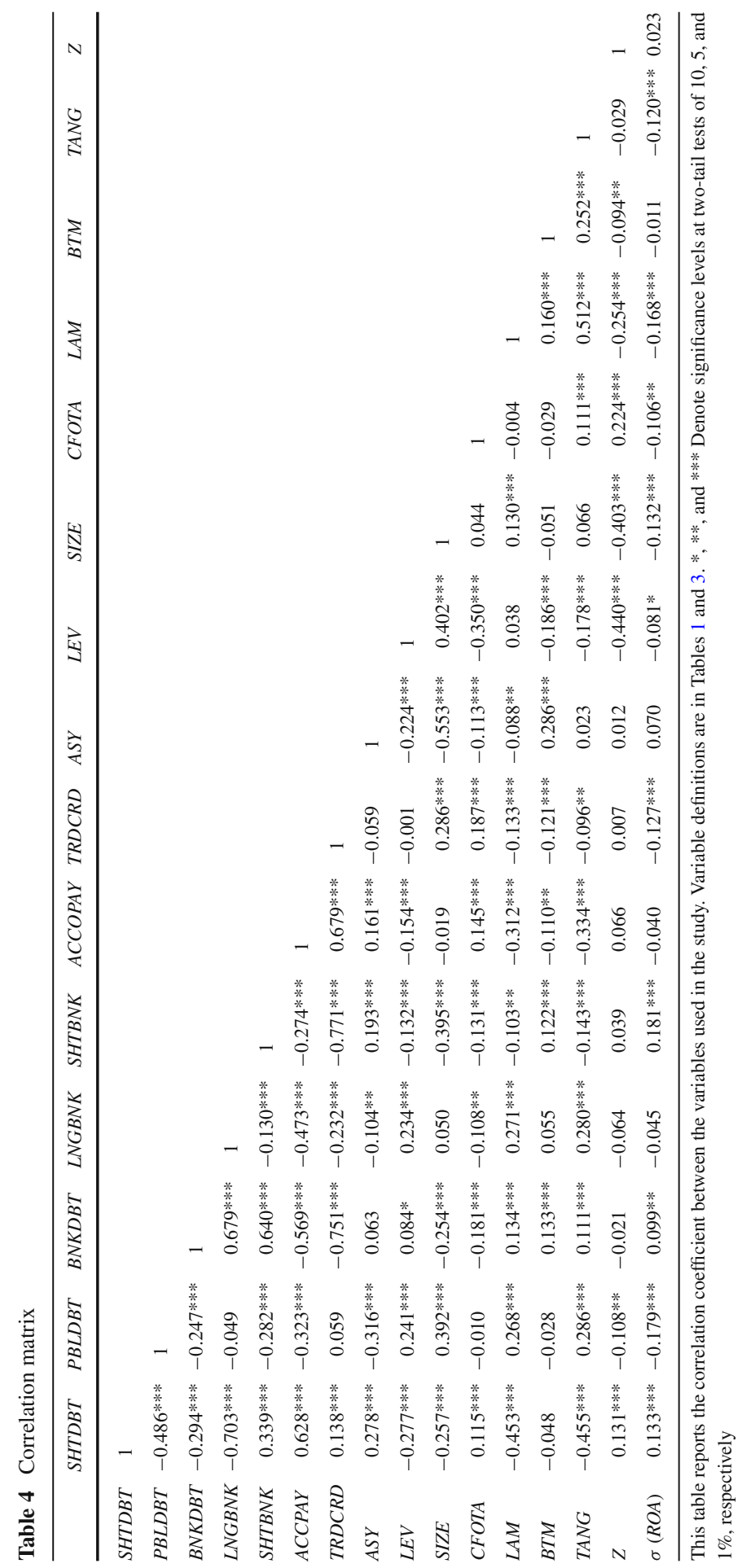


alternatives of short-term financing, SHTBANK and ACCPAY, are negatively associated with each other (at the $1 \%$ level), which suggests that they may be substitutive financial choices. The results also show that bigger firms and more indebted firms use more public debt and less short-term debt (at the 1\% level). Likewise, we do not detect high correlations between independent variables, which suggests that there are no multicollinearity problems.

Our proxy for information asymmetry (ASY) shows a positive and significant association with $S H T D E B T$ at the $1 \%$ level. Additionally, $A S Y$ is negatively correlated with $P B L D T$ and $L N G B N K$ (at $1 \%$ level and 5\% level, respectively). This suggests that when the level of information asymmetry increases, firms have more difficulties to access the public debt market and long-term financing from banks. On the contrary, the two types of short-term debt (SHTBNK and ACCPAY) are significantly and positively correlated with the level of information asymmetry, which suggests that under information asymmetry firms have to rely on short-term financing sources. Nevertheless, firm size shows a significant negative correlation with $S H T B N K$ (at the $1 \%$ level) and it is not significantly correlated with $A C C P A Y$. At the same time, as expected, the correlation between SIZE and $A S Y$ is -0.553 , significant at the $1 \%$ level, which is consistent with prior studies that show that small firms have usually a poorer information environment than larger firms (e.g. Chung et al. 1995; Lakonishok and Lee 2001).

Since extensive research suggests that there are systematic differences in the information environment depending on firm's size, we classify firms into small and large firms splitting the sample by the median of SIZE. Table 5 presents the descriptive statistics of the main variables for small and large firms. We find significant differences in the variables regarding financing sources and the level of information asymmetry between these two groups of firms. Consistent with prior literature (e.g. Bougheas et al. 2006), small firms tend to have a higher percentage of short-term debt than larger firms. In our sample, the mean of SHTDBT is $65.15 \%$ in small firms, whereas the average of this variable in large firms is $53.70 \%$, and this difference is significant at the $1 \%$ level. In addition, larger firms present significant higher levels of public debt, PBLDBT, than small ones (10.68 vs. $1.33 \%)$. On the contrary, the percentage of bank debt, and particularly short-term bank debt, over total debt is significantly higher in small firms than in larger ones.Within short-term financing sources, ACCPAY is more relevant in small firms than in large firms (28.6 vs. $26.1 \%$ ), with this difference being significant at the $10 \%$ level. Due to the lower values of SHTBNK in large firms in comparison to small firms, TRDCRD is higher in larger firms (67.6 vs. 56.4\%), a difference which is significant at the $1 \%$ level.

Summarizing, these results suggest that larger firms can obtain debt financing from the capital market, mainly long-term, and thus need less long-term financial funds from banks. In contrast, smaller firms have more difficulties to access the public debt market and also to obtain long-term financing in the private debt market, so their main external financing sources consists in short-term bank debt and accounts payable. Finally, as expected, large firms present significant lower levels of information asymmetry than small firms at the $1 \%$ level, and $A S Y$ shows a lower dispersion in the subsample of large firms than in the small ones. 
Table 5 Differences between small and large firms

\begin{tabular}{|c|c|c|c|c|c|c|c|}
\hline & \multicolumn{3}{|l|}{ Small } & \multicolumn{3}{|l|}{ Large } & \multirow{2}{*}{$\begin{array}{l}\text { Difference } \\
\text { Mean }\end{array}$} \\
\hline & \#obs. & Mean & $\mathrm{SD}$ & \#obs. & Mean & SD & \\
\hline SHTDBT & 271 & 0.6515 & 0.1994 & 272 & 0.5370 & 0.2109 & $0.115^{* * *} *$ \\
\hline$P B L D B T$ & 271 & 0.0133 & 0.0508 & 272 & 0.1068 & 0.1499 & $-0.093 * * *$ \\
\hline$B N K D B T$ & 271 & 0.4241 & 0.2231 & 272 & 0.3393 & 0.1920 & $0.085 * * *$ \\
\hline$L N G B N K$ & 271 & 0.1995 & 0.1661 & 272 & 0.2264 & 0.1621 & $-0.027 *$ \\
\hline$S H T B N K$ & 271 & 0.2245 & 0.1765 & 272 & 0.1129 & 0.1099 & $0.112 * * *$ \\
\hline АССРАY & 271 & 0.2858 & 0.1712 & 272 & 0.2609 & 0.1754 & $0.025^{*}$ \\
\hline TRDCRD & 271 & 0.5644 & 0.2499 & 272 & 0.6759 & 0.2232 & $-0.112 * * *$ \\
\hline$A S Y$ & 271 & 1.0228 & 1.8189 & 271 & -1.0228 & 0.9941 & $2.046^{* * * *}$ \\
\hline
\end{tabular}

This table presents the descriptive statistics of short-financing and information asymmetry variables and the differences in these variables among small and large firms. We define as small firms those where SIZE has a value lower (higher) than its median. Variable definitions are in Tables 1 and 3 . The $t$ test is used to test the null hypothesis of no significant differences in each information asymmetry proxy between two subsamples. * **, and *** Denote significance levels at two-tail tests of 10,5 , and $1 \%$, respectively

\subsection{Multivariate analyses}

We assess the association between information asymmetry and debt financing through seven OLS regressions with clustered (Rogers) standard errors at the firm level (Petersen 2009), robust both to heteroskedasticity and within-firm serial correlation, as described in model (1). Table 6 reports the results for the whole sample for the different debt type ratios used as dependent variables.

In column 1 of Table 6 we find that the coefficient on $A S Y$ is positive and statistically significant (1\% level) as a determinant of SHTDBT, suggesting that higher information asymmetry is significantly associated with higher levels of short-term debt once we control for other variables. This finding is consistent not only with prior research based on the traditional proxies for information asymmetry from corporate finance literature (e.g. Barclay and Smith 1995; Cuñat 1999; Berger et al. 2005; García-Teruel et al. 2010; González Méndez 2013), but also with the findings in Gao and Zhu (2015) employing measures from market microstructure. With regard to control variables, similar to prior evidence, firms with higher leverage show less proportion of shortterm debt (at the $1 \%$ level), whereas those firms that generate more cash flows show a higher proportion of short-term debt (at the $5 \%$ level). In addition, and also consistent with prior research, we find that firms with longer asset maturities and more collateral show a longer debt maturity structure (at the $1 \%$ level).

Going beyond prior studies, we focus on how the extent of information asymmetry affects short-term financing sources. Nevertheless, the choice between the two main sources of short-term financing (bank debt and accounts payable) may be determined by the existence of financial constraints in other sources of debt financing, as suggested by the previous descriptive analyses. In order to examine this issue, we first analyze the effects of information asymmetries on public debt, total bank debt, and longterm bank debt. As seen in columns 2 and 3 of Table 6, we find that $A S Y$ has a 
Table 6 Effect of information asymmetry on different types of debt

\begin{tabular}{|c|c|c|c|c|c|c|c|}
\hline & SHTDBT & $P B L D B T$ & $B N K D B T$ & $L N G B N K$ & SHTBNK & АССРАY & $T R D C R D$ \\
\hline$A S Y$ & $\begin{array}{l}0.089 * * * \\
(2.87)\end{array}$ & $\begin{array}{l}-0.046^{* * *} \\
(-2.21)\end{array}$ & $\begin{array}{l}-0.099 * * * \\
(-2.93)\end{array}$ & $\begin{array}{l}-0.039 \\
(-1.46)\end{array}$ & $\begin{array}{l}-0.063 * * * \\
(-2.73)\end{array}$ & $\begin{array}{l}0.120 * * * \\
(4.49)\end{array}$ & $\begin{array}{l}0.156^{* * *} \\
(3.64)\end{array}$ \\
\hline$L E V$ & $\begin{array}{l}-0.327 * * * \\
(-4.30)\end{array}$ & $\begin{array}{l}0.115^{* * * *} \\
(2.76)\end{array}$ & $\begin{array}{l}0.200^{* *} \\
(2.08)\end{array}$ & $\begin{array}{l}0.287 * * * \\
(3.60)\end{array}$ & $\begin{array}{l}-0.093 \\
(-1.23)\end{array}$ & $\begin{array}{l}-0.198 * * * \\
(-3.09)\end{array}$ & $\begin{array}{l}-0.087 \\
(-0.73)\end{array}$ \\
\hline SIZE & $\begin{array}{l}0.010 \\
(0.88)\end{array}$ & $\begin{array}{l}0.008 \\
(1.01)\end{array}$ & $\begin{array}{l}-0.049 * * * \\
(-3.96)\end{array}$ & $\begin{array}{l}-0.014 \\
(-1.45)\end{array}$ & $\begin{array}{l}-0.035^{* * *} \\
(-3.75)\end{array}$ & $\begin{array}{l}0.028 * * * \\
(2.84)\end{array}$ & $\begin{array}{l}0.059 * * * \\
(4.09)\end{array}$ \\
\hline CFOTA & $\begin{array}{l}0.293 * * \\
(2.23)\end{array}$ & $\begin{array}{l}-0.054 \\
(-0.88)\end{array}$ & $\begin{array}{l}-0.240 \\
(-1.61)\end{array}$ & $\begin{array}{l}-0.108 \\
(-1.14)\end{array}$ & $\begin{array}{l}-0.136 \\
(-1.15)\end{array}$ & $\begin{array}{l}0.240 * * \\
(2.54)\end{array}$ & $\begin{array}{l}0.357 * \\
(1.78)\end{array}$ \\
\hline$L A M$ & $\begin{array}{l}-0.049 * * * \\
(-2.92)\end{array}$ & & & $\begin{array}{l}0.016 \\
(1.00)\end{array}$ & $\begin{array}{l}-0.030 * * \\
(-2.03)\end{array}$ & $\begin{array}{l}-0.020 \\
(-1.27)\end{array}$ & \\
\hline BTM & $\begin{array}{l}-0.032 \\
(-1.38)\end{array}$ & $\begin{array}{l}0.005 \\
(0.33)\end{array}$ & $\begin{array}{l}0.053 * * \\
(2.07)\end{array}$ & $\begin{array}{l}0.022 \\
(0.88)\end{array}$ & $\begin{array}{l}0.031 * \\
(1.90)\end{array}$ & $\begin{array}{l}-0.033^{*} \\
(-1.96)\end{array}$ & $\begin{array}{l}-0.036 \\
(-1.44)\end{array}$ \\
\hline$T A N G$ & $\begin{array}{l}-0.383^{* * * *} \\
(-4.64)\end{array}$ & $\begin{array}{l}0.155^{* * * *} \\
(2.74)\end{array}$ & $\begin{array}{l}0.164 * \\
(1.89)\end{array}$ & $\begin{array}{l}0.219 \text { *** } \\
(2.77)\end{array}$ & $\begin{array}{l}-0.026 \\
(-0.43)\end{array}$ & $\begin{array}{l}-0.243^{* * *} \\
(-3.60)\end{array}$ & $\begin{array}{l}-0.182 * \\
(-1.89)\end{array}$ \\
\hline$Z$ & $\begin{array}{l}-0.024 \\
(-0.91)\end{array}$ & $\begin{array}{l}0.008 \\
(0.81)\end{array}$ & $\begin{array}{l}-0.035 \\
(-1.19)\end{array}$ & $\begin{array}{l}0.022 \\
(0.87)\end{array}$ & $\begin{array}{l}-0.064 * * * \\
(-3.74)\end{array}$ & $\begin{array}{l}0.018 \\
(0.91)\end{array}$ & $\begin{array}{l}0.071 * * \\
(2.14)\end{array}$ \\
\hline$\sigma(R O A)$ & $\begin{array}{l}0.219 \\
(0.73)\end{array}$ & $\begin{array}{l}-0.342 * * \\
(-2.32)\end{array}$ & $\begin{array}{l}0.578 \\
(1.45)\end{array}$ & $\begin{array}{l}0.025 \\
(0.09\end{array}$ & $\begin{array}{l}0.494 * \\
(1.70)\end{array}$ & $\begin{array}{l}-0.415 \\
(-1.55)\end{array}$ & $\begin{array}{l}-0.665 \\
(-1.55)\end{array}$ \\
\hline Intercept & $\begin{array}{l}0.777 * * * \\
(3.50)\end{array}$ & $\begin{array}{l}-0.099 \\
(-0.69)\end{array}$ & $\begin{array}{l}0.953^{* * * *} \\
(4.41)\end{array}$ & $\begin{array}{l}0.163 \\
(0.84)\end{array}$ & $\begin{array}{l}0.820 * * * \\
(4.43)\end{array}$ & $\begin{array}{l}-0.011 \\
(-0.06)\end{array}$ & $\begin{array}{l}-0.229 \\
(-0.86)\end{array}$ \\
\hline Indust. dum. & Yes & Yes & Yes & Yes & Yes & Yes & Yes \\
\hline Year dum. & Yes & Yes & Yes & Yes & Yes & Yes & Yes \\
\hline$R^{2}$ & 0.464 & 0.309 & 0.333 & 0.222 & 0.388 & 0.377 & 0.347 \\
\hline \#obs. & 542 & 542 & 542 & 542 & 542 & 542 & 542 \\
\hline
\end{tabular}

This table reports OLS coefficients of the regression model (1), using different debt type ratios as dependent variables, for the whole sample. Variable definitions are in Tables 1 and 3 . The $t$ statistics reported in parentheses are based on Rogers standard errors clustered at the firm level. *,**, and *** Denote significance levels at two-tail tests of 10,5 , and $1 \%$, respectively

significant and negative relationship with $P B L D B T$ and BNKDBT (at the 5 and $1 \%$ levels, respectively). ${ }^{8}$ These findings imply that those firms with more information asymmetry have more difficulties to issue market debt and to access bank financing. These findings are consistent with the evidence on US listed firms reported by Shen (2014), which suggests that firms with high levels of information asymmetry lose their access to the public debt market and have to rely on the private debt market. With regard to long-term bank debt (column 4), the coefficient on $A S Y$ is negative and nonsignificant at conventional levels in a two-tail test, although the negative association

\footnotetext{
8 When we break down public debt by maturity, we also find that our proxy of information asymmetry is negatively associated with long-term and short-term public debt (at 10\% level). We do not tabulate these results for space reasons, but they are available upon request.
} 
between $A S Y$ and $L N G B N K$ would be statistically significant at the $10 \%$ level in a one-tail test.

Focusing on the short-term financing sources (columns 5 and 6), we observe that the coefficient on $A S Y$ is negative and highly significant in the short-term bank debt regression, whereas we find a positive association of $A S Y$ with $A C C O P A Y$ (at the $1 \%$ level). These results are consistent with those in column 7 , which indicate a positive association between $A S Y$ and TRADCRD. In other words, firms with higher information asymmetry have a higher proportion of trade credit over short-term bank financing in their financial structure. Overall, our findings suggest that the financing provided by suppliers increases when the level of information asymmetry of a firm is higher. Consequently, trade credit seems to relieve the difficulties of firms that, as a consequence of information asymmetries, face restrictions in their access to the capital market and suffer credit rationing imposed by banks. ${ }^{9}$

With regard to control variables, we obtain results consistent with prior evidence on financing determinants. Our findings show the relevance of collateral to obtain certain financial resources. TANG, our proxy for the firm's collateral, is statistically significant in the majority of regressions. Prior research has reported a positive relationship between collateral and long-term debt (e.g. Bougheas et al. 2006), showing that collateral is an important determinant in the granting of credit, particularly for long-term loans conceded by financial institutions (e.g. Berger and Udell 1990). In our case, TANG is positively associated with public debt and bank-debt, basically with long-term bank debt, and negatively related to short-term debt and accounts payable. Therefore, our results suggest that those firms with more levels of collateralizable assets have more access to long-term financing and have less dependence on shortterm financing, especially on financing provided by suppliers.

According to Niskanen and Niskanen (2000), we also report that those firms with higher levels of operating cash flows over total assets present higher levels of shortterm financing and trade credit. In addition, and consistent with Cuñat (1999) and García-Teruel et al. (2010), among others, we also observe that more indebted firms prefer long-term debt to short-term debt, but we additionally find that these firms show higher levels of public debt and bank financing (in particular, long-term bank debt) and lower levels of financing provided by suppliers. The coefficient on BTM in the regression of $B N K D B T$ is positive and significant at the 5\% level. This result, in line with previous evidence (e.g. Denis and Mihov 2003; De Andrés Alonso et al. 2005), suggests that firms with poorer expectations of value creation use more bank debt. In other words, firms with profitable investment opportunities avoid this type of financing since the bank supervision reduces the firm's flexibility to take advantage of their growth opportunities (De Andrés Alonso et al. 2005). Moreover, we observe that larger firms reveal a greater presence of trade credit and less short-term bank financing. Similarly, firms with higher financial strength also show less short-term bank debt, and consequently, an increase in the proportion of trade credit in the short-term financing sources.

\footnotetext{
9 We obtain the same results if we consider in TRADCRD all bank debt (short- and long-term), confirming the substitution effect between bank debt and accounts payable.
} 
Additionally, we conduct the regression analyses above splitting the firms into two groups according to SIZE. Panels A and B of Table 7 report the effects of information asymmetry on firm short-term financing decisions for small and large firms, respectively. The findings from the subsample of small firms are very similar to those of the whole sample. The coefficients on $A S Y$ and their significance levels suggest that small firms with greater informational asymmetries have shorter debt maturity, less access to public debt and bank financing, and, consequently, they have to rely more on other short-term non-bank financing sources, such as trade credit. Our findings seem to be consistent with Petersen and Rajan (1997) and Biais and Gollier (1997) as they suggest that those firms where asymmetric information generates credit rationing, such as small firms, use more trade credit.

However, as seen in Panel B, the level of information asymmetry does not affect SHTDBT, PBLDT, BNKDBT, LNGBNK, and ACCPAY for large firms. By contrast, we observe that the coefficient on $A S Y$ is negative in the $S H T B N K$ regression (significant at the $10 \%$ level) and positive in the TRDCRD model (at the 5\% level). Therefore, although it is less clear than in the small firms group, we also observe that larger firms that suffer higher levels of information asymmetry, the weight of trade credit over short-term financing increases. In this case, this finding is due to information asymmetries making the access to short-term bank debt more difficult, since we do not find a significant association with the financing provided by suppliers. Therefore, our findings suggest that financing decisions are less sensitive to information asymmetry in larger listed firms, probably because in this type of firms the adverse selection problem is less severe than in smaller listed-firms.

\subsection{Robustness checks}

We have implemented several sensitivity analyses to assess the robustness of our results. One concern in our results is that they may be caused by some omitted factors. For instance, as shown in Tables 2 and 4, firm's size and age are both correlated with information asymmetry, and size is also correlated with different types of debt. Therefore, it could be that size and age are both correlated with asymmetric information and debt financing, while there is no causal link between information asymmetry and capital structure. Thus, in order to discard the possibility that factors, such as size and age, could be causing our results, we have run regressions with growingly saturated age and size controls.

Panel A of Table 8 shows the coefficients on $A S Y$ for different saturated versions of model (1), where we have included polynomials on SIZE and Age. Since these coefficients are quite stable from the simplest models to the more saturated models on size and age, these findings suggest that ASY contains information beyond SIZE and Age that is relevant for capital structure. In addition, we have performed two other tests. First, we have orthogonalised SIZE and ASY, by regressing ASY on SIZE, and taking the residuals as the part of $A S Y$ which is not explained by $S I Z E\left(r_{-} A S Y\right)$. Second, we have regressed $A S Y$ on $S I Z E$ and $A g e$, and we have taken the residuals as the part of $A S Y$ which is not explained by SIZE and Age ( $\left.z \_A S Y\right)$. Then, we include $r \_A S Y$ or $z_{\_} A S Y$ in the original model with size or size and age controls, respectively, instead 
Table 7 Effect of information asymmetry on different types of debt by size

\begin{tabular}{|c|c|c|c|c|c|c|c|}
\hline & SHTDBT & $P B L D B T$ & $B N K D B T$ & $L N G B N K$ & SHTBNK & АССРАY & $T R D C R D$ \\
\hline \multicolumn{8}{|c|}{ Panel A: Small firms } \\
\hline$A S Y$ & $\begin{array}{l}0.090 * * \\
(2.28)\end{array}$ & $\begin{array}{l}-0.018 * * \\
(-2.01)\end{array}$ & $\begin{array}{l}-0.114 * * \\
(-2.54)\end{array}$ & $\begin{array}{l}-0.051 \\
(-1.50)\end{array}$ & $\begin{array}{l}-0.073 \\
(-1.35)\end{array}$ & $\begin{array}{l}0.151 * * * \\
(5.04)\end{array}$ & $\begin{array}{l}0.172 * * * \\
(2.68)\end{array}$ \\
\hline$L E V$ & $\begin{array}{l}-0.365^{* * *} \\
(-4.16)\end{array}$ & $\begin{array}{l}0.033^{*} \\
(1.84)\end{array}$ & $\begin{array}{l}0.319 * * * \\
(2.93)\end{array}$ & $\begin{array}{l}0.341^{* * * *} \\
(3.60)\end{array}$ & $\begin{array}{l}-0.044 \\
(-0.57)\end{array}$ & $\begin{array}{l}-0.198 * * \\
(-2.56)\end{array}$ & $\begin{array}{l}-0.208^{*} \\
(-1.84)\end{array}$ \\
\hline SIZE & $\begin{array}{l}0.014 \\
(0.91)\end{array}$ & $\begin{array}{l}0.001 \\
(0.18)\end{array}$ & $\begin{array}{l}-0.052 * * \\
(-2.60)\end{array}$ & $\begin{array}{l}0.002 \\
(0.14)\end{array}$ & $\begin{array}{l}-0.056^{* * * *} \\
(-2.73)\end{array}$ & $\begin{array}{l}0.051 * * * \\
(3.79)\end{array}$ & $\begin{array}{l}0.081 * * * \\
(3.64)\end{array}$ \\
\hline CFOTA & $\begin{array}{l}0.361 * * * \\
(3.33)\end{array}$ & $\begin{array}{l}-0.014 \\
(-0.51)\end{array}$ & $\begin{array}{l}-0.215 \\
(-1.45)\end{array}$ & $\begin{array}{l}-0.143 \\
(-1.49)\end{array}$ & $\begin{array}{l}-0.082 \\
(-0.68)\end{array}$ & $\begin{array}{l}0.278^{* * * *} \\
(3.08)\end{array}$ & $\begin{array}{l}0.321 \\
(1.55)\end{array}$ \\
\hline$L A M$ & $\begin{array}{l}-0.043 * \\
(-1.70)\end{array}$ & & & $\begin{array}{l}0.021 \\
(1.05)\end{array}$ & $\begin{array}{l}-0.053^{* *} \\
(-2.62)\end{array}$ & $\begin{array}{l}0.009 \\
(0.64)\end{array}$ & \\
\hline$B T M$ & $\begin{array}{l}-0.032 \\
(-1.24)\end{array}$ & $\begin{array}{l}-0.4 \cdot 10^{-3} \\
(0.09)\end{array}$ & $\begin{array}{l}0.055^{*} \\
(1.80)\end{array}$ & $\begin{array}{l}0.023 \\
(0.73)\end{array}$ & $\begin{array}{l}0.031 * \\
(1.76)\end{array}$ & $\begin{array}{l}-0.051 * * * \\
(-2.82)\end{array}$ & $\begin{array}{l}-0.051^{* * * *} \\
(-2.00)\end{array}$ \\
\hline$T A N G$ & $\begin{array}{l}-0.297 * * \\
(-2.59)\end{array}$ & $\begin{array}{l}0.051 * * \\
(2.13)\end{array}$ & $\begin{array}{l}0.076 \\
(0.63)\end{array}$ & $\begin{array}{l}0.145 \\
(1.39)\end{array}$ & $\begin{array}{l}-0.005 \\
(-0.05)\end{array}$ & $\begin{array}{l}-0.236 * * * \\
(-2.78)\end{array}$ & $\begin{array}{l}-0.131 \\
(-1.00)\end{array}$ \\
\hline$Z$ & $\begin{array}{l}-0.031 \\
(-1.29)\end{array}$ & $\begin{array}{l}0.004 \\
(0.53)\end{array}$ & $\begin{array}{l}-0.034 \\
(-1.06)\end{array}$ & $\begin{array}{l}0.045^{*} \\
(1.82)\end{array}$ & $\begin{array}{l}-0.098 * * * \\
(-3.77)\end{array}$ & $\begin{array}{l}0.050 * * * \\
(2.83)\end{array}$ & $\begin{array}{l}0.088^{* *} \\
(2.48)\end{array}$ \\
\hline$\sigma(R O A)$ & $\begin{array}{l}0.431 \\
(1.26)\end{array}$ & $\begin{array}{l}-0.050 \\
(-0.57)\end{array}$ & $\begin{array}{l}0.150 \\
(0.29)\end{array}$ & $\begin{array}{l}-0.216 \\
(-0.58)\end{array}$ & $\begin{array}{l}0.192 \\
(0.47)\end{array}$ & $\begin{array}{l}-0.089 \\
(-0.32)\end{array}$ & $\begin{array}{l}-0.325 \\
(-0.61)\end{array}$ \\
\hline Intercept & $\begin{array}{l}0.731 \text { *** } \\
(2.74)\end{array}$ & $\begin{array}{l}0.067 \\
(0.87)\end{array}$ & $\begin{array}{l}0.963 * * * \\
(3.45)\end{array}$ & $\begin{array}{l}-0.068 \\
(-0.27)\end{array}$ & $\begin{array}{l}1.139 * * * \\
(3.86)\end{array}$ & $\begin{array}{l}-0.410 * * \\
(-2.24)\end{array}$ & $\begin{array}{l}-0.493 \\
(-1.48)\end{array}$ \\
\hline Indust. dum. & Yes & Yes & Yes & Yes & Yes & Yes & Yes \\
\hline Year dum. & Yes & Yes & Yes & Yes & Yes & Yes & Yes \\
\hline$R^{2}$ & 0.376 & 0.228 & 0.409 & 0.272 & 0.363 & 0.442 & 0.416 \\
\hline \#obs. & 271 & 271 & 271 & 271 & 271 & 271 & 271 \\
\hline \multicolumn{8}{|c|}{ Panel B: Large firms } \\
\hline$A S Y$ & $\begin{array}{l}-0.020 \\
(-0.42)\end{array}$ & $\begin{array}{l}0.003 \\
(0.07)\end{array}$ & $\begin{array}{l}-0.078 \\
(-1.17)\end{array}$ & $\begin{array}{l}-0.020 \\
(-0.40)\end{array}$ & $\begin{array}{l}-0.058 * \\
(-1.88)\end{array}$ & $\begin{array}{l}0.022 \\
(0.42)\end{array}$ & $\begin{array}{l}0.143 * * \\
(2.06)\end{array}$ \\
\hline$L E V$ & $\begin{array}{l}0.641 * * \\
(2.44)\end{array}$ & $\begin{array}{l}-0.042 \\
(-0.18)\end{array}$ & $\begin{array}{l}-0.434 \\
(-1.07)\end{array}$ & $\begin{array}{l}-0.028 \\
(-0.10)\end{array}$ & $\begin{array}{l}-0.398 * * \\
(-2.28)\end{array}$ & $\begin{array}{l}0.442 * \\
(1.71)\end{array}$ & $\begin{array}{l}0.666 \\
(1.45)\end{array}$ \\
\hline SIZE & $\begin{array}{l}-0.034 \\
(-1.43)\end{array}$ & $\begin{array}{l}0.027 \\
(1.27)\end{array}$ & $\begin{array}{l}-0.034 \\
(-1.16)\end{array}$ & $\begin{array}{l}-0.023 \\
(-1.11)\end{array}$ & $\begin{array}{l}-0.010 \\
(-0.93)\end{array}$ & $\begin{array}{l}-0.023 \\
(-0.78)\end{array}$ & $\begin{array}{l}0.020 \\
(0.65)\end{array}$ \\
\hline CFOTA & $\begin{array}{l}-0.146 \\
(-0.29)\end{array}$ & $\begin{array}{l}0.191 \\
(0.96)\end{array}$ & $\begin{array}{l}-0.496 \\
(-1.17)\end{array}$ & $\begin{array}{l}-0.062 \\
(-0.16)\end{array}$ & $\begin{array}{l}-0.440 \\
(-1.47)\end{array}$ & $\begin{array}{l}-0.023 \\
(-0.06)\end{array}$ & $\begin{array}{l}0.639 \\
(1.46)\end{array}$ \\
\hline$L A M$ & $\begin{array}{l}-0.049 * * \\
(-2.19)\end{array}$ & & & $\begin{array}{l}0.008 \\
(0.27)\end{array}$ & $\begin{array}{l}0.002 \\
(0.13)\end{array}$ & $\begin{array}{l}-0.053^{* *} \\
(-2.06)\end{array}$ & \\
\hline$B T M$ & $\begin{array}{l}0.007 \\
(0.17)\end{array}$ & $\begin{array}{l}-0.013 \\
(-0.28)\end{array}$ & $\begin{array}{l}0.036 \\
(0.53)\end{array}$ & $\begin{array}{l}0.014 \\
(0.33)\end{array}$ & $\begin{array}{l}0.021 \\
(0.46)\end{array}$ & $\begin{array}{l}0.052 \\
(1.34)\end{array}$ & $\begin{array}{l}0.023 \\
(0.30)\end{array}$ \\
\hline
\end{tabular}


Table 7 continued

\begin{tabular}{llllllll}
\hline & SHTDBT & PBLDBT & BNKDBT & LNGBNK & SHTBNK & ACCPAY & TRDCRD \\
\hline TANG & $-0.333^{* * *}$ & $0.242^{*}$ & 0.161 & $0.232^{*}$ & -0.094 & $-0.213^{*}$ & -0.192 \\
& $(-3.21)$ & $(1.99)$ & $(1.16)$ & $(1.78)$ & $(-1.20)$ & $(-1.90)$ & $(-1.42)$ \\
$Z$ & $0.742^{* * *}$ & $-0.299^{* *}$ & -0.278 & -0.176 & -0.090 & $0.481^{* *}$ & 0.325 \\
& $(3.55)$ & $(-2.03)$ & $(-0.98)$ & $(-0.86)$ & $(-0.67)$ & $(2.53)$ & $(1.00)$ \\
$\sigma($ ROA $)$ & 0.043 & -0.276 & 0.700 & 0.185 & 0.534 & -0.645 & -0.568 \\
& $(0.07)$ & $(-0.94)$ & $(1.19)$ & $(0.35)$ & $(1.31)$ & $(-1.18)$ & $(-0.95)$ \\
Intercept & 0.563 & -0.227 & $1.249 * *$ & 0.586 & $0.643 * * *$ & 0.244 & -0.276 \\
& $(1.40)$ & $(-0.57)$ & $(2.51)$ & $(1.50)$ & $(3.58)$ & $(0.61)$ & $(-0.58)$ \\
Indust. dum. & Yes & Yes & Yes & Yes & Yes & Yes & Yes \\
Year dum. & Yes & Yes & Yes & Yes & Yes & Yes & Yes \\
$R^{2}$ & 0.573 & 0.296 & 0.268 & 0.231 & 0.344 & 0.446 & 0.312 \\
\#obs. & 271 & 271 & 271 & 271 & 271 & 271 & 271 \\
\hline
\end{tabular}

This table reports OLS coefficients of the regression model (1), using different debt type ratios as dependent variables, for small firms (Panel A) and large firms (Panel B). Variable definitions are in Tables 1 and 3. The $t$ statistics reported in parentheses are based on Rogers standard errors clustered at the firm level. *, $* *$, and $* * *$ Denote significance levels at two-tail tests of 10,5 , and $1 \%$, respectively

Table 8 Coefficients on ASY for different versions of model (1)

\begin{tabular}{|c|c|c|c|c|c|c|c|}
\hline & SHTDBT & $P B L D B T$ & $B N K D B T$ & $L N G B N K$ & SHTBNK & АCCPAY & $T R D C R D$ \\
\hline \multicolumn{8}{|c|}{ Panel A: Saturated model (1) on SIZE and Age } \\
\hline SIZE, Age & $0.087 * * *$ & $-0.047 * *$ & $-0.098 * * *$ & -0.037 & $-0.064 * * *$ & $0.120 * * *$ & $0.156^{* * *}$ \\
\hline $\begin{array}{l}S I Z E, S I Z E^{2}, \\
\text { Age, Age }\end{array}$ & $0.084 * * *$ & $-0.041 * *$ & $-0.086^{* *}$ & -0.039 & $-0.050 * *$ & $0.111 * * *$ & $0.137 * * *$ \\
\hline $\begin{array}{l}\text { SIZE, SIZE } \\
\text { SIZE } \\
\text { Age }^{3} \text {, Age, } \\
\text { Age }^{3}\end{array}$ & $0.089 * * *$ & $-0.045^{* *}$ & $-0.087 * *$ & -0.044 & $-0.046^{* *}$ & $0.110 * * *$ & $0.134 * * *$ \\
\hline \multicolumn{8}{|c|}{ Panel B: Model (1) with orthogonalized $A S Y$} \\
\hline$r_{-} A S Y$ & $0.089 * * *$ & $-0.046^{* *}$ & $-0.099 * * *$ & -0.039 & $-0.063 * * *$ & $0.120 * * *$ & $0.156 * * *$ \\
\hline z_ASY & $0.087 * * *$ & $-0.047 * *$ & $-0.098 * * *$ & -0.037 & $-0.064 * * *$ & $0.120 * * *$ & $0.156 * * *$ \\
\hline
\end{tabular}

This table reports estimates for the coefficient on $A S Y$ in different versions of model (1). Panel A shows the coefficients on ASY from regressions of model (1) with growingly saturated SIZE and Age controls. Panel B reports the estimates for the coefficient on orthogonalized $A S Y$ in the model (1): $r_{-} A S Y$ is the residuals of the regression of $A S Y$ on SIZE and $z_{-} A S Y$ is the residuals of the regression of ASY on SIZE and Age. ASY is the composite index of information asymmetry based on market microstructure measures of information asymmetry. SIZE is the logarithm of sales. Age is the logarithm of the numbers of years since the inception. $* *$, and *** Denote significance levels at two-tail tests of 5 and $1 \%$, respectively, assessed with Rogers standard errors clustered at the firm level

of our original $A S Y$ variable. The results, as shown in the Panel B of Table 8, are also significant and the coefficients on $r_{-} A S Y$ or $z_{\_} A S Y$ are very stable. Overall, all these findings suggest that the effect of $A S Y$ on firm's debt financing decisions is not caused by firm size and age. 
We also addressed the possibility of reverse causality. Specifically, there are theoretical arguments to expect that the firm's debt structure generates equity risk (in the line of Modigliani-Miller's Proposition II) that, in turn, may affect the constituents of $A S Y$. This argument mostly applies for total leverage (not considered in our study) and it could be less relevant with respect to the composition of debt. To examine whether the different types of debt affect equity risk, we regress idiosyncratic risk against each one of our types of debt ratio controlling by variables identified in prior literature as related to equity risk. Our findings (not tabulated) indicate that the debt type ratios used as dependent variables in our paper do not significantly affect the equity risk and, consequently, that our findings are not driven by this reverse causality concern.

\section{Conclusions}

In this paper, we use an information asymmetry index based on measures developed by market microstructure to investigate the association between information asymmetry and the debt financing decisions of firms. For a sample of Spanish listed companies, we document that as information asymmetry increases, firms shorten their debt maturity. Similarly, we find that higher information asymmetry negatively affects public leverage and bank debt, in particular short-term bank financing. In contrast, we observe a positive relationship between information asymmetry and trade credit. These findings suggest that firms with more information asymmetries face more restrictions in their efforts to obtain financing from both public debt-market and banking entities, so they are forced to turn to seeking finance from suppliers. Therefore, within short-term financing sources, we document a higher (lower) use of trade credit (short-term bank debt) as the level of information asymmetry increases.

We also show that the impact of information asymmetry on debt financing decisions is moderated by firm size. The findings for the whole sample are mainly attributed to small firms, which are those that face more problems relating to information asymmetries. Thus, whereas in the small firm's subsample we find evidence similar to that of the whole sample in relation to debt maturity, public debt, bank debt and accounts payable, we do not find this evidence in larger listed firms. This could be explained by larger firms being characterized by a more transparent information environment that diminishes the monitoring role of short-term debt and enhances the firm's access to broader financing sources. Nevertheless, in large firms we do find an increase in the relative importance of trade credit within short-term financing sources as the degree of information asymmetry increases. However, in this case this effect could be attributed to the reduction in short-term bank debt, since the level of accounts payable is not affected by information asymmetry.

Overall, our findings support those models framed within the information asymmetry theories of trade credit, in which suppliers can relieve credit rationing suffered by firms as a consequence of information asymmetries (e.g. Smith 1987; Biais and Gollier 1997; Burkart and Ellingsen 2004). Thus, our paper is in the line of prior empirical research that shows that firms which are financially constrained and rationed in the credit market use trade credit from their suppliers to a greater extent (e.g. Petersen and 
Rajan 1997; Nilsen 2002; Danielson and Scott 2004; Cuñat 2007; Garcia-Appendini and Montoriol-Garriga 2013).

Our study contributes to the literature on the effects of information asymmetry on financing decisions, and in particular on the role played by trade credit and suppliers under financial restrictions. Considerable empirical evidence exists concerning this topic, fundamentally focused on small and medium sized firms. However, the information asymmetry theories of trade credit have scarcely been investigated on listed firms. To the best of our knowledge, there are no similar studies examining the composition of short-term financing for Spanish listed firms. Prior studies regarding the Spanish listed firms' financing have focused on the determinants of capital structure and debt maturity (e.g. Cuñat 1999; De Andrés Alonso et al. 2005; García-Teruel and Martínez-Solano 2010; García-Teruel et al. 2010) as well as the use of bank debt (Ojah and Manrique 2005; Saona and Vallelado 2010). We also extend the recent literature about information asymmetry and capital structure using market microstructure-based measures of information asymmetry (e.g. Bharath et al. 2009; Gao and Zhu 2015; Shen 2014; Petacchi 2015). Our study is the first paper that uses these types of proxies to analyze if trade credit is used to circumvent the financial restrictions imposed by information asymmetries. Market microstructure proxies may be more appropriate for measuring information asymmetries suffered by a listed firm, since the traditional measures from corporate finance literature (such as firm size, age, growth-opportunities, etc.) may be capturing other details not directly related to information asymmetry, especially in the case of large firms, such as those listed on a stock market.

Acknowledgements David Abad acknowledges financial support from the Ministerio de Economía y Competitividad through Grants ECO2013-4409-P and ECO2014-58434-P. We thank two anonymous referees, the Co-Editor Manuel Bagues, and the Editor-in-Chief, Nezih Guner, for their helpful comments and suggestions, which have improved the paper greatly. José Yagüe acknowledges financial support from Fundación Caja Murcia.

Open Access This article is distributed under the terms of the Creative Commons Attribution 4.0 International License (http://creativecommons.org/licenses/by/4.0/), which permits unrestricted use, distribution, and reproduction in any medium, provided you give appropriate credit to the original author(s) and the source, provide a link to the Creative Commons license, and indicate if changes were made.

Publisher's Note Springer Nature remains neutral with regard to jurisdictional claims in published maps and institutional affiliations.

\section{References}

Abad D, Yagüe J (2012) From PIN to VPIN: an introduction to order flow toxicity. Span Rev Financ Econ 10:74-83

Agarwal P, O’Hara M (2007) Information risk and capital structure. Working paper. http://papers.ssrn.com/ sol3/papers.cfm?abstract_id=939663

Akay O, Cyree KB, Griffiths MD, Winters DB (2012) What does PIN identify? Evidence from the T-bill market. J Financ Mark 15:29-46

Amihud Y (2002) Illiquidity and stock returns: cross-section and time-series effects. J Financ Mark 5:31-56

Anderson CW, Makhija AK (1999) Deregulation, disintermediation, and agency cost of debt: evidence from Japan. J Financ Econ 51:309-339

Atiase RK (1985) Predisclosure information, firm capitalization, and security price behavior around earnings announcements. J Account Res 23:21-36 
Barry CB, Brown SJ (1984) Differential information and the small firm effect. J Financ Econ 13:283-294

Barclay M, Smith C (1995) The maturity structure of corporate debt. J Finance 50:609-631

Begley K, Ming B, Watts R (1996) Bankruptcy classification errors in 1980s: an empirical analysis of Altman's and Ohlson' models. Rev Account Stud 1:267-284

Berger AN, Espinosa-Vega MA, Frame WS, Miller NH (2005) Debt maturity, risk, and asymmetric information. J Finance 60:2895-2923

Berger AN, Udell GF (1990) Collateral, loan quality and bank risk. J Monet Econ 25:21-42

Bharath ST, Pasquariello P, Wu G (2009) Does asymmetric information drive capital structure decisions? Rev Financ Stud 22:3211-3243

Bharath ST, Sunder J, Sunder SV (2008) Accounting quality and debt contracting. Account Rev 83:1-28

Bhattacharya N, Desai H, Venkataraman K (2013) Does earnings quality affect information asymmetry? Evidence from trading costs. Contemp Account Res 30:482-516

Bhushan R (1989) Firm characteristics and analyst following. J Account Econ 11:255-274

Biais B, Gollier C (1997) Trade credit and credit rationing. Rev Financ Stud 10:903-937

Bougheas S, Mizen P, Yalcin C (2006) Access to external finance: Theory and evidence on the impact of monetary policy and firm-specific characteristics. J Bank Finance 30:199-227

Brown S, Hillegeist S (2007) How disclosure quality affects the level of information asymmetry. Rev Account Stud 12:443-477

Burkart M, Ellingsen T (2004) In-Kind Finance: a theory of trade credit. Am Econ Rev 94:569-590

Chung KH, McInish TH, Wood RA, Wyhowski DJ (1995) Production of information, information asymmetry, and the bid-ask spread: empirical evidence from analysts' forecasts. J Bank Finance 19:1025-1046

Cuñat V (1999) Determinantes del plazo de endeudamiento de las empresas españolas. Investig Econ 23:351-392

Cuñat V (2007) Trade credit: suppliers as debt collectors and insurance providers. Rev Financ Stud 20:491527

Danielson MG, Scott JA (2004) Bank loan availability and trade credit demand. Financ Rev 39:579-600

Datta S, Iskandar-Datta M, Raman K (2005) Managerial stock ownership and the maturity structure of corporate debt. J Finance 60:2333-2350

De Andrés Alonso P, López Iturriaga FJ, Rodríguez Sanz JA, Vallelado González E (2005) Determinants of bank debt in a continental financial system: evidence from Spanish companies. Financ Rev 40:305-333

Demirgüç-Kunt A, Maksimovic V (1999) Institutions, financial markets, and firm debt maturity. J Financ Econ 54:295-336

Demirgüç-Kunt A, Maksimovic V (2002) Funding growth in bank-based and market-based financial systems: evidence from firm-level data. J Financ Econ 65:337-363

Denis DJ, Mihov VT (2003) The choice among bank debt, non-bank private debt, and public debt: evidence from new corporate borrowings. J Financ Econ 70:3-28

Diamond DW (1984) Financial Intermediation and delegated monitoring. Rev Econ Stud 51:393-414

Diamond DW (1991) Monitoring and reputation: the choice between bank loans and directly placed debt. J Polit Econ 99:689-721

Easley D, Kiefer N, O'Hara M (1997) One day in the life of a very common stock. Rev Financ Stud 10:805-835

Easley D, López de Prado MM, O’Hara M (2012) Flow toxicity and liquidity in a high-frequency world. Rev Financ Stud 25:1457-1493

Easley D, Nicholas MK, O’Hara M, Paperman J (1996) Liquidity, information, and infrequently traded stocks. J Finance 51:1405-1436

Faccio M, Lang L (2002) The ultimate ownership of Western European corporations. J Financ Econ 65:365395

Fama E (1985) What's different about banks? J Monet Econ 15:29-39

Flannery MJ (1986) Asymmetric information and risky debt maturity choice. J Finance 41:19-37

Gao W, Zhu F (2015) Information asymmetry and capital structure around the world. Pac Basin Finance J 32:131-159

Garcia-Appendini E, Montoriol-Garriga J (2013) Firms as liquidity providers: evidence from the 2007-2008 financial crisis. J Financ Econ 109:272-291

García-Teruel PJ, Martínez-Solano P (2010) Ownership structure and debt maturity: new evidence from Spain. Rev Quant Finance Account 35:473-491

García-Teruel PJ, Martínez-Solano P, Sánchez-Ballesta JP (2010) Accruals quality and debt maturity structure. Abacus 46:188-210 
García-Teruel PJ, Martínez-Solano P, Sánchez-Ballesta JP (2014a) Supplier financing and earnings quality. J Bus Finance Account 41:1193-1211

García-Teruel PJ, Martínez-Solano P, Sánchez-Ballesta JP (2014b) The role of accruals quality in the access to bank debt. J Bank Finance 38:186-193

Glosten LR, Milgrom PR (1985) Bid, ask and transaction prices in a specialist market with heterogeneousIy informed traders. J Financ Econ 14:71-100

González Méndez V (2013) Determinants of debt maturity structure across firm size. Span J Finance Account 42:187-209

Huang R, Stoll H (1996) Dealer versus auction markets: a paired comparison of execution costs on NASDAQ and NYSE. J Financ Econ 41:313-357

Jain N (2001) Monitoring costs and trade credit. Q Rev Econ Finance 41:89-110

Johnson S (1997) An empirical analysis of the determinants of the corporate debt ownership structure. J Financ Quant Anal 32:47-69

Klein LS, O’Brien TJ, Peters SR (2002) Debt vs. equity and asymmetric information: a review. Financ Rev 37:317-350

La Porta R, Lopez de Salines F, Shleifer A, Vishny RW (1998) Law and finance. J Polit Econ 106:1113-1155

Lakonishok J, Lee I (2001) Are insider trades informative? Rev Financ Stud 14:79-111

Leland HE, Pyle DH (1977) Informational asymmetries, financial structure, and financial intermediation. J Finance 32:371-387

Love I (2011) Trade credit versus bank credit during financial crisis. In: Chauffour JP, Malouche M (eds) Trade finance during the great trade collapse. The World Bank, Washington, DC, pp 27-39

Magri S (2010) Debt maturity choice of nonpublic Italian firms. J Money Credit Bank 42:443-463

Marotta G (2005) Is trade credit more expensive than bank loans? Evidence from Italian firm-level data. Appl Econ 37:403-416

Myers S, Majluf N (1984) Corporate financing and investment decisions when firms have information that investor do not have. J Financ Econ 13:187-221

Nilsen JH (2002) Trade credit and the bank lending channel. J Money Credit Bank 34:226-253

Niskanen J, Niskanen M (2000) Accounts receivable and accounts payable in large Finnish firms' balance sheets: what determines their levels? Finn J Bus Econ 49:124-143

Ojah K, Manrique J (2005) Determinants of corporate debt structure in a privately dominated debt market: a study of the Spanish capital market. Appl Financ Econ 15:455-468

Petacchi R (2015) Information asymmetry and capital structure: evidence from regulation FD. J Account Econ 59:143-162

Petersen M, Rajan RG (1997) Trade credit: theories and evidence. Rev Financ Stud 10:661-691

Petersen MA (2009) Estimating standard errors in finance panel data sets: comparing approaches. Rev Financ Stud 22:435-480

Rajan RG, Zingales L (1995) What do we know about capital structure? Some evidence from international data. J Finance 50:1421-1460

Saona P, Vallelado E (2010) Is the use of bank debt as a governance mechanism conditioned by the financial system? The cases of Chile and Spain. Appl Econ 42:1709-1726

Scherr FC, Hulburt HM (2001) The debt maturity structure of small firms. Financ Manag 30:85-111

Schmidt R, Tyrell M (1997) Financial systems, corporate finance and corporate governance. Eur Financ Manag 3:333-361

Shen CH (2014) Pecking order, access to public debt market, and information asymmetry. Int Rev Econ Finance 29:291-306

Smith JK (1987) Trade credit and information asymmetry. J Finance 42:863-872

Stiglitz JE, Weiss A (1981) Credit rationing in markets with imperfect information. Am Econ Rev 71:393410

Stohs MH, Mauer DC (1996) The determinants of corporate debt maturity structure. J Bus 69:279-312 